This Journal is available in Telkom University online Journals

Jurnal Manajemen Indonesia

\title{
Analysis of the Accounting Credibility of Garuda Indonesia Financial Transactions with Mahata Aero Teknologi
}

\author{
Girang Permata Gusti ${ }^{1}$, Agnes Bieattant Budianto ${ }^{2}$ \\ ${ }^{1}$ Sekolah Tinggi Ilmu Ekonomi Boedi Oetomo, Pontianak, Indonesia \\ ${ }^{2}$ Martin-Luther-University Halle-Wittenberg, German
}

\begin{abstract}
This study aims to analyze the credibility of recorded financial statements from 2018 carried out by Garuda Indonesia, specifically transactions conducted by Garuda companies with Mahata. Using descriptive research methods, which include case studies and document review, the results obtained show that the transaction entitlement to the payment commitment by Mahata to Garuda, which is recorded in the other income section, is incorrect. It should not be recognized as other income based on Pernyataan Standar Akuntansi Keuangan (PSAK) 23 "revenue." Instead, revenue recognition of rights compensation costs should be based on the PSAK 30 "rent." Also, there are indications that Mahata was neither able to carry out at least part of its large scope of work nor could it pay the fees for compensation rights, according to the invoice deadline.
\end{abstract}

Keywords - Garuda Indonesia, Mahata, Accrual based, Cash-based

\begin{abstract}
Abstrak
Penelitian ini bertujuan untuk menganalisis kelayakan pencatatan laporan keuangan pada tahun 2018 yang dilakukan oleh Garuda Indonesia, khususnya transaksi yang dilakukan oleh Garuda dengan Mahata. Menggunakan metode penelitian deskriptif, yang meliputi studi kasus dan tinjauan dokumen. Hasil yang diperoleh adalah bahwa hak transaksi untuk komitmen pembayaran oleh Mahata kepada Garuda yang dicatat di bagian pendapatan lainnya tidak benar, yang tidak boleh diakui sebagai pendapatan lain berdasarkan PSAK 23 "pendapatan", pengakuan pendapatan dari kompensasi hak biaya harus diakui berdasarkan PSAK 30 "sewa". Selain itu ada indikasi ketidakmampuan Mahata untuk melakukan bagian dari itu lingkup pekerjaan yang besar dan membayar biaya kompensasi sesuai dengan batas waktu dari faktur.
\end{abstract}

Kata kunci - Garuda Indonesia, Mahata, Berbasis akrual, Berbasis uang tunai

\section{INTRODUCTION}

Placement of transaction commitments made by Garuda Indonesia with Mahata Aero Teknologi in a separate income section of its 2018 financial report, raises red flags. The Garuda Party insists that its financial statements are by existing accounting standard guidelines, but many parties consider its financial statements to be "window dressing." From negative US\$213.39 million in income in 2017, Garuda was able by the next year to report a very significant positive income of US\$5.02 million. This sparked a debate over the accounting methods used by Garuda auditors in preparing their statements, considering that the total operating income in 2018 was US $\$ 4.37$ billion, lower than the total operating expenses of US\$4.58 billion. The new figures represented a substantial increase over the airline's 2017 income of US\$19.80 million. In the 2018 report, the income had jumped to US\$278.81 million. The windfall set off debate and polemic which led the House of Representatives of the Republic of Indonesia to summon the Garuda Directors for an explanation and to have their financial statements re-examined by the Republic of Indonesia Supreme Audit Agency regarding the 
suitability of their preparation based upon the Statement of Financial Accounting Standards (Pernyataan Standar Akuntansi Keuangan, PSAK).

After tracing very carefully on the financial statements, the US \$239.94 million figures were found as compensation revenues (in the form of payment commitments) from Mahata to Garuda, where the commitment of this compensation then Garuda obliged to ensure the number of passengers is always in the amount of 45-55 million people annually over the next fifteen years, the aim to provide a mutually beneficial business relationship between Garuda and Mahata, Mahata will benefit from the advertisements that will be seen by each passenger when they use the onboard Internet facility, with the estimated profit per passenger who saw the advertisement for $\$ 1$, then Mahata opportunity to run the commitment of payment that has been made to Garuda will be very logical to achieve. However, problems arise when Garuda places the position of this commitment fund on the other profits on the financial statements.

Declaring that number as income was polemical and inspired multiple interpretations, especially as the money had not yet been received. It was argued that income promised yet still not received should rightfully be recorded as accounts receivable. The placement of that figure as income is what the writer is trying to examine: is it truly justified by the preparation of accounting standards or not?

This problem arose after two Garuda commissioners, namely Chairal Tanjung (PT. Trans Airways) and Dony Oskaria (Fine gold Resources Ltd), both of whose companies are co-owners and shareholders of Garuda Indonesia, refused to sign the financial statements in 2018 or register their companies' cooperation, because of no payment from Mahata until the end of 2018.

\section{Literature REVIEW}

Rahayu (2015) mentions that the basic concept of accrual basis is applied in two ways. First, revenue recognition is done when a company has the authority to collect for its business activities, such as the sale of goods and/or services. Recognition of this income does not require the cash to have been received, so it is feasible for uncollectible accounts. Second is the recognition of costs and expenses. This is recognized when the company must pay even though it has not made the equivalent payment. Other explanations have been offered by Ferryono and Sutaryo (2017). According to the Republic of Indonesia Government Regulation PP 71 of 2010 , the accrual basis is an accounting method that recognizes the effects of transactions and other events when they occur, regardless of when cash or cash equivalents are received or paid.

According to Sugiyanto, Rasyid et al. (2014), accrual basis applies when economic transactions or accounting events are recognized, recorded, and presented in financial statements, based on their effect at the time they occur, regardless of when the cash is paid or received. It may be used to measure assets, liabilities, and fund equity, or allowed for sales on credit. Another explanation is provided by AkuntansiPedia (2017). For example, income recognition is crucial in measuring the performance of an entity. The Financial Accounting Standard Board, Dewan Standard Akuntansi Keuangan, has made a Statement of Financial Accounting Standards called PSAK, regarding income, as stated in PSAK 23. PSAK 23 discusses income adopted from the International Accounting Standard 18 (IAS 18). According to PSAK 23, income is the gross cash inflow from the economic benefits arising from anentity's normal activities during a period, if the inflow results in an increase in equity that does not originate from an investment.

Rustam (2002) mentions that revenues arising from a company's normal activities have certain identifications. According to PSAK No.23, the criteria for revenue recognition are usually applied separately to each transaction, but in certain circumstances, it is necessary to apply the recognition criteria to components that can be identified separately from a single transaction to reflect the substance of the transaction. Conversely, the recognition criterion is applied to two or more transactions together if are bound in such a way that the commercial influence cannot be understood without looking at the entire set of transactions. DosenAkuntansi (2018) states that receivable income is income that has become a right in terms of time but has not been recorded or received as payment. In this case, the company must collect or continue to remind the buyers to make payments so that the company immediately receives the income. Income receivables are usually recorded in adjustment journals by writing accounts in the form of accounts receivable in the debit transaction and income name, according to the name of the receivables on the credit side. 
According to Ayu (2018), accounting on an accrual basis is a technique of accounting records, the recording of which is done at the time of the transaction even though cash has not been received. In the recording, using an accrual basis is certainly more accurate, and using an asset, liability, and equity accrual basis is easily measured. On an accrual basis, an income will be recognized when the company has the right to collect from the transaction. Using this accrual basis, it does not matter when the cash is issued or received. Recognition of fees on an accrual basis occurs when the obligation to pay is due. These costs can already be recognized when the obligation to pay has occurred, even though the cash has not been issued. Then by Utami (2018, 14 August) Accounting methods on an accrual basis record money when billed and obtained, regardless of when the money enters one's account. This means that one may have to record income before they physically receive the money. This method is a little more nuanced but is very good for providing a holistic view of a company's finances.

Finansialku (2017) states that accrual-based accounting allows for economic transactions or accounting events to be recognized, recorded, and presented in financial statements based on the effect of the transaction at the time it occurs, regardless of when the cash is paid or received. Recognition of income on an accrual basis occurs when the company has the right to collect from the results of the company's activities. In the concept of accrual basis, the point at which the cash is accepted becomes less important. Therefore, an estimate of uncollectible receivables appears because the income has been recognized, even though the cash has not yet been received. Rahayu (2015) mentions that the basic cash concept is applied in two ways. First, by revenue recognition, new income is recognized if the company receives payments in cash. Being less important about when the right to collect occurs, this method eliminates accounts receivable directly. Second, about recognizing costs and expenses, costs are recognized when payments are made in cash.

As described by Ayu (2018), accounting with a cash basis only records transactions if there is a cash receipt or expenditure. So, even though transactions occur, such as debts or accounts receivable, the transaction is not recorded because there is no cash in or out. For example, if you receive income from other companies but receive the money later, the transaction will not be recorded. Thus, there is no cash coming in, and there is no income, per se.Utami (2018)further describes how accounting on a cash basis is considered business income only when payments arrive and business expenses are recorded when paid. Cash ignores any receivables or debts, i.e. unpaid bills or payments.

According to Afandi (2018), paragraph 22 of the Basic Framework for Preparation and Presentation of Financial Statements, Financial Accounting Standards, Standar Akuntansi Keuangan (SAK) states that "To achieve its objectives, financial statements are prepared on an accrual basis." As such, the effects of transactions and other events are recognized at the time of the event, not when cash or cash equivalents are received or paid, recorded in the accounting records, or reported in the financial statements for the period concerned. Paragraph 8 of PSAP 01, concerning the Presentation of Government Accounting Standards, Pernyataan Standar Akuntansi Pemerintahan (PSAP) Financial Statements states that "Accrual basis is an accounting method that recognizes the effect of transactions and other events as they occur, regardless of when cash or cash equivalents are received or paid". Still, according to Afandi (2018), recognition of revenue according to Government Accounting Standards, Standar Akuntansi Pemerintahan (SAP), Paragraph 19 of the PSAP 12 Income-LO, states that "Low Income is recognized as (1) the emergence of rights to income, and (2) realized revenue, namely the flow of economic resources to an entity". The emergence of rights to income can be interpreted as the right of an entity to an income, but the obligatory payer has not made a payment (or the payment has not accrued). It can also mean that the entity has received the payment but does not have the right to recognize the income, and therefore the recognition of the payment is deferred. Thus, when connected with cash flow, "the emergence of the right to income", can be used to recognize income that has not yet been received, or that has been received but has not yet become the entity's right by adjusting their income.

\section{RESEARCH METHODS}

This research uses the descriptive method, which, according to Sunyoto (2013), aims to describe the nature of something that is going on at the same time the research is conducted, to examine the causes of a particular symptom. According to Sugiyono (2013), the descriptive method means that the purpose of the study is to describe or photograph the object in question. The research includes case studies and document research. The case study will be a detailed analysis of a particular object during a certain period, and overall, will include the environment and conditions of the past (Sunyoto 2013). Document research aims to collect data and information through testing archives and related evidence(Sunyoto 2013). 
The data and information obtained will be compared and interpreted, and then conclusions will be drawn. The relationships of various data and information obtained will be used as references for drawing conclusions based on the literature and the study of existing theories.

\section{DISCUSSION}

The increase in Garuda's operating income over the past 10 years was followed by a commensurate rise in operating expenses, which were higher in value than the business itself. The situation resulted in fluctuating movements in the company's net income, which showed a persistent instability each year, as seen in Table 1 and Graph 1.

Table 1. Garuda Indonesia, 2009-2018 Income Statement

\begin{tabular}{llll}
\hline Period & Operating Income (US \$ Billion) & Operating Expenses (US \$ Billion) & Net Profit (US \$ Million) \\
\hline $\mathbf{2 0 0 9}$ & 1.86 & 1.96 & 98.95 \\
$\mathbf{2 0 1 0}$ & 2.24 & 2.25 & 39.85 \\
$\mathbf{2 0 1 1}$ & 3.10 & 3.00 & 64.22 \\
$\mathbf{2 0 1 2}$ & 3.47 & 3.30 & 110.84 \\
$\mathbf{2 0 1 3}$ & 3.72 & 3.71 & 11.20 \\
$\mathbf{2 0 1 4}$ & 3.93 & 4.29 & $(368.91)$ \\
$\mathbf{2 0 1 5}$ & 3.81 & 3.73 & 77.97 \\
$\mathbf{2 0 1 6}$ & 3.86 & 3.79 & 9.36 \\
$\mathbf{2 0 1 7}$ & 4.18 & 4.24 & $(213.39)$ \\
$\mathbf{2 0 1 8}$ & 4.37 & 4.58 & 5.02 \\
$\mathbf{2 0 1 8} *$ & 4.37 & 4.58 & $(175.03)$ \\
\hline
\end{tabular}

Source: Garuda Indonesia Tbk Annual Financial Report. *): Revision

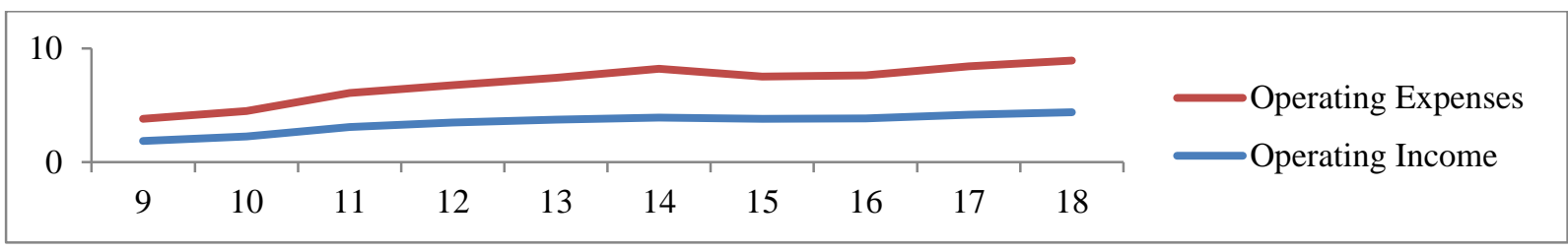

Figure 1. Garuda Indonesia Expenses and Income Statement(US \$ Billion), from 2009 to 2018 (Source: Garuda Indonesia Tbk Annual Financial Report)

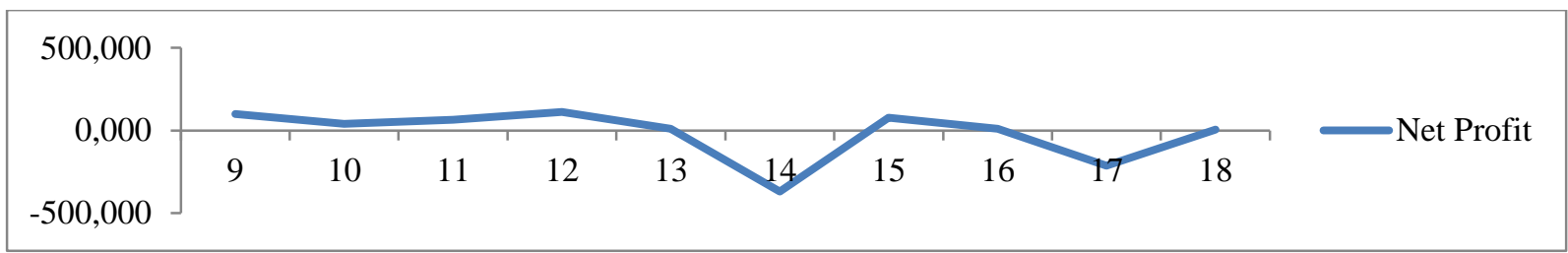

Figure 2. Garuda Indonesia Net Profit Statement(US \$ Million) from 2009 to 2018

(Source: Garuda Indonesia Tbk Annual Financial Report)

The debate over the chaotic Garuda financial statements, starting with the Mahata commitments to Garuda that had yet to be paid, and recorded on other income for the 2018 reporting period, are detailed in Table 2.

The concern in the placement of every transaction made is important, so as not to cause future problems. Logical explanations and guidelines based on accounting standards are vital to always use. Following the article written by Sukmana (2019, 29 April) the receivables transaction that ignited the debate stemmed from a cooperation contract providing in-flight WiFi connectivity services and aircraft entertainment from PT Mahata 
Aero Teknologi. Garuda Director of Engineering and Services, Iwan Joeniarto, said that the connectivity service contract was mutually beneficial. In the cooperation agreement, Iwan continued, there were two transactions, namely a compensation fee for installing in-flight entertainment connectivity and management services. The second half involved profit sharing for slot allocation on each aircraft connected over the life of the contract period.

Table 2. Details of Garuda's income statement, other income items (US\$ million).

\begin{tabular}{lc}
\hline List of Transactions & Amount \\
\hline Installation RightsforConnectivity Services for 153 Garuda Aircraft & 131.94 \\
Management Rights for entertainment Services and Content Management for 99 Garuda Aircraft & 80 \\
Profit-sharing from PT Sriwijaya Air & 28 \\
\hline Payment Commitment from Mahata Aero Technology & 239.94 \\
\hline Source: Garuda Indonesia Tbk Annual Financial Report. &
\end{tabular}

The following are the contents of the agreement between Mahata and Garuda, the details of the compensation commitments given to Garuda as described by Melani (2019, 29 April). Citing the company's financial statements submitted to the Indonesia Stock Exchange (IDX) on October 31, 2018, Garuda Indonesia and PT Mahata Aero Teknologi entered into an amended cooperation agreement. The second version was signed on December 26, 2018, regarding the provision of connectivity services in the aviation, in-flight entertainment, and content management. Mahata would carry out and bear all costs of providing, implementing, installing, operating, maintaining, and unloading. Maintenance would include, in the event of damage, replacing and repairing connectivity service equipment in aviation, in-flight entertainment, and content management. Mahata agreed to pay compensation for the installation rights of the in-flight connectivity services for 50 A320 aircraft, 20 A330 aircraft, 73 Boeing 737-800 NG aircraft, and 10 Boeing 777 aircraft for US\$131,940,000. Add to that, compensation fees to Garuda Indonesia for the management of aircraft entertainment services and content management for 18 A3330 aircraft, 70 Boeing 737-800 NG aircraft, 1 Boeing 737800 Max aircraft, and 10 Boeing 777 aircraft, for US\$80 million upon the signing of the cooperation agreement. The remuneration received for the submission of the installation and management rights mentioned above would be a fixed benefit or a non-refundable guarantee in an irrevocable contract that allowed the right holder to exploit that right freely. Nor did the right provider have the remaining obligation to carry it out. Installation rights, connectivity service equipment, and management rights for in-flight entertainment services, plus content, amount to US\$21,194,000. That revenue was recognized when the rights were handed over to Mahata in December 2018. Garuda Indonesia was to evaluate every two months the implementation of the agreement. If the evaluation results indicated that the agreement was not profitable for Garuda Indonesia. In this case, Mahata does not carry out its obligations and responsibilities. Garuda has the right to terminate the cooperation agreement and all rights and obligations that have not been resolved and/or have arisen as a result of the application of the cooperation agreement and must be completed no later than 14 days after the cooperation agreement ends. The cooperation agreement is valid for 15 years. At present, the pattern of slot allocation for the 11th to 15th year has not been determined.

At the general meeting of shareholders, two Garuda commissioners expressed objections to the placement of the compensating commitments made by Mahata, as written by Rosana (2019, 15 April). The annual GIAA financial report is referred to as contradictory to the Statement of Financial Accounting Standards (Pernyataan Standar Akuntansi Keuangan - PSAK) 23 which states income must be measured by fixed income or guarantees that cannot be returned in an irrevocable contract. Judging from the agreement with Mahata, until the report was released, two commissioners said that one of the considerations of their objection was that no payment had been made, even though there had been a realization of the installation of a unit of connectivity equipment in Citilink. According to Chairal and Dony, this report will "mislead" the public because Garuda Indonesia recorded a significant loss to profit. "Moreover, the company is a public or open company." Besides, there are potential changes in the financial statement that can damage credibility, which results in cash flow or cash flow burden.

\section{The following is an excerpt from parties who agree that the placement of Mahata payments is listed on other income posts.}

Sugianto (2019) says that PT Mahata Aero Teknologi is the savior of the 2018 financial statements of PT Garuda Indonesia Tbk. The company managed to make a profit because of the accounts receivable from the collaboration with Mahata, which included as income. Garuda Indonesia Business Director Pikri Ilham Kurniansyah said, "The Garuda company believes that Mahata can handle this collaboration with professionals. 
The company (Garuda) claimed to have carried out the GCG process before choosing Mahata as a cooperation partner. Now, the main reason Garuda Indonesia chose Mahata because was a startup company. It is brave to provide WiFi technology without payment. Even as the collaboration concept, Mahata is the one who pays Garuda, whereas, with the previous WiFi collaboration, Garuda had to pay every month in advance. This is a new business model. Another company (Mahata) installs the WiFi at Garuda, then pays the Garuda for the privilege!.

According to Pratomo (2019), Public Accounting Firm, Tanubrata Sutanto Fahmi Bambang, and colleagues explained that when referring to PSAK 23 (Statement of Financial Accounting Standards), paragraph 14, the sale transaction rights for the connectivity service equipment and management rights of in-flight entertainment can be recognized as sales revenue if certain conditions have been met: First, Garuda Group must have submitted installation rights to connectivity service equipment and management rights of in-flight entertainment at the time the agreement was signed. All ownership benefits previously recorded as Garuda Group's revenue is terminated and submitted to Mahata. Second, the entity no longer continues management which is usually related to ownership of goods, or it takes effective control of goods sold. Based on the agreement, Garuda Group has submitted installation rights, connectivity, and entertainment services to Mahata. Third, the amount of income can be measured reliably. In the agreement, the cost of compensation for installation rights for connectivity service equipment was US\$92.94 million for 103 Garuda aircraft, US\$39 million for 50 aircraft Citilink, and US\$30 million for 50 Sriwijaya aircraft. Meanwhile, the cost of compensation for the management rights of in-flight entertainment services and content management is worth US\$80 million for 99 Garuda aircraft. Fourth, it is likely that the economic benefits associated with the transaction will flow to the entity. Fifth, costs incurred in connection with sales transactions can be reliably measured.

Based on Pradana (2019), according to Garuda Indonesia Director of Finance \& Risk Management Fuad Rizal, transactions with Mahata are following the Statement of Financial Accounting Standards, known as Pernyataan Standar Akuntansi Keuangan 23, or PSAK 23, because the revenue substance can be recorded before cash is received. PSAK 23 distinguishes three categories of income recognition, namely goods sales, service sales, and interest income, royalties, and dividends. Meanwhile, all stipulate the criteria for recognition of income, specifically income that can be measured reliably, the economic benefits that will flow to the entity, and the transfer of risk. In line with the results of the audit of Public accounting firm (KAP) Tanubrata Sutanto Fahmi Bambang \& Partners, a member of BDO International, it was stated that, in the auditor's opinion, the financial statements have been fairly presented in all material and/or unqualified matters. "Management believes that the recognition of income from compensation costs for transactions with Mahata is by applicable Financial Accounting Standards. As a Big 5 Audit Firm, BDO should have implemented very good international audit standards," said Fuad.

Ibrahim and Binekasri (2019), mention that the management of PT Garuda Indonesia (Persero) Tbk insists that the financial statements of the 2018 fiscal year do not violate the rules set out in the Statement of Financial Accounting Standards (PSAK) 23. This statement follows the refusal of two commissioners to sign the 2018 financial report, because of including accounts receivable as income violations of PSAK 23. Finance Director of Garuda Indonesia Fuad Rizal conveyed, based on PSAK 23, that there are three economic transactions and events that could be recognized as income. First and second are the sale of goods and the sale of services. The third is the use of company assets by other parties that generate interest, royalties, and dividends. All three can be recognized as income if they can be reliably measured. There are economic benefits that will flow to the entity and there is a transfer of risk". So, it does not violate the financial accounting standard (PSAK) 23, because the revenue substance can be recorded before cash is received. There is nothing violated by the company because it includes receivables into income," Fuad said.

The following is an excerpt from parties who do not agree that the placement of Mahata payments is listed on other income posts.

According to CNN-Indonesia (2019), two Garuda Indonesia commissioners, Chairal Tanjung and Dony Oskaria, refused to sign the Garuda 2018 yearbook report. The two were representatives of PT Trans Airways and Fine gold Resources Ltd, respectively, as owners and holders of 28.08 percent of Garuda Indonesia shares. They did not agree with one of the collaborative transactions with PT Mahata Aero Teknologi, which was recorded as revenue by management. In a letter obtained by the media when the Annual General Meeting of Shareholders (AGMS) it was written that Mahata worked directly with PT Citilink Indonesia. Through the agreement, the profits achieved by the Garuda Indonesia Group amounted to US\$239,940,000, of 
whichUS\$28,000,000 was profit sharing between Garuda Indonesia and PT Sriwijaya Air. However, Garuda has not received payment from Mahata for cooperation that has been done. Nevertheless, the management still writes it as income, so in accounting, Indonesia Garuda suddenly gets net profit after the previous loss of US $\$ 216.58$ million. The irregularities expressed by the two commissioners through this letter did not change management's attitude. In the Annual General Meeting of Shareholders (AGMS), the financial statements of Garuda Indonesia were received by the majority of shareholders last year (2018).

Still based on articles written by CNN-Indonesia (2019), upon further examination, connectivity services in aviation and entertainment were derived from the cooperation agreement signed by Garuda Indonesia with Mahata on October 31, 2018, and updated on December 26, 2018. In that collaboration, Mahata is committed to bearing all costs of providing, implementing, installing, operating, maintaining, and dismantling, including for damage, replacement, or repair of equipment connectivity services. Installation of in-flight service equipment was installed for 50 A320-type Garuda Indonesia aircraft, 20 A330 aircraft, 73 Boeing 737-800 NG aircraft, and 10 Boeing 777 aircraft, with a total value of US\$131.94 million. Then, entertainment services were installed on 18 A330-type aircraft, 70 Boeing 737-800 NG aircraft, one Boeing 737-800 Max aircraft, and 10 Boeing 777 aircraft, with a total value of US\$80 million. In referring to the Chairal and Donyletter, Mahatahad not made any payments at all, from the agreed compensation of US\$239.94 million to Garuda Indonesia through the end of 2018. However, management decided to list it as revenue. Chairal and Dony said that without compensation, the company was still losing US\$244.95 million. The management decision did succeed in making the market complacent with a positive note in the financial statements, as still described by CNN-Indonesia (2019). However, Chairal and Dony argue that this is detrimental to the company in terms of cash flow. Because there is an obligation to pay Income Tax (PPh) and Value Added Tax from the profits earned by Garuda Indonesia.

Sukmana (2019) writes that the PT Garuda Indonesia in 2018 was problematic because of placing receivables into income. This also caused two Garuda commissioners to reject the financial statements. Responding to the debate, the red plate airline management said that it did not violate the Financial Accounting Standards (PSAK) 23 because, according to Garuda, the lion's share of the revenue could be recorded before the cash was received. Garuda also said that its financial statements have been presented fairly in all material matters. This is in line with the results of the public accounting firm (KAP) Tanubrata Sutanto Fahmi Bambang \& Partners (a member of the BDO International) audit, which is one of the Big 5 Accounting Firms Worldwide (Mufti, 2019).

The two commissioners of PT Garuda Indonesia Tbk Chairal Tanjung and Dony Oskaria are representatives of PT Trans Airways and Fine gold Resources Ltd, respectively. Together, as owners and shareholders, they control 28.08 percent of all shares issued by the company. The two commissioners objected to the recording of the financial statements submitted in the documents at the PT Garuda Indonesia Tbk AGMS. They considered the cooperation agreement to provide in-flight connectivity services signed by PT Mahata Aero Technology (Mahata) and PT Citilink Indonesia on October 31, 2018, together with amendments (Mahata Agreement) with the company's revenues of US\$239,940,000 amounting to US\$28,000,000 can not be recognized in the fiscal year 2018 as part of the results of the company obtained from PT Sriwijaya Air. Recognition of income from the Mahata agreement by the company amounted to US $\$ 239,940,000$. By recognizing revenue from the Mahata agreement, the company posted a profit of US \$5,018,308 (Melani (2019). Then again, without that recognition, the company would experience a loss of US $\$ 244,958,308$.

According to Melani (2019), the Ministry of Finance of the Republic of Indonesia completed the audit of the public accounting firm, Tanubrata Sutanto Fahmi Bambang, and Partners (International Member of BOD) regarding the 2018 financial statements of PT Garuda Indonesia Tbk (Persero) Tbk. This firm is an auditor for Garuda Indonesia's financial reports that had received considerable flak for their astonishing revenue claim. "In conclusion, there are allegations relating to the implementation of the audit that has not fully followed the applicable accounting standards," said Secretary of the Ministry of Finance Hadiyanto. Meanwhile, Chairman of the Indonesian Institute of Certified Public Accountants (Institut Akuntan Publik Indonesia - IAPI), Tarko Sunaryo said, the directors of PT Garuda Indonesia Tbk needed to coordinate with auditors to improve Garuda Indonesia's financial reports for the fiscal year 2018. He said that IAPI had also reviewed transactions between Mahata and Garuda Indonesia, based on information available in the public, both in financial statements and information disclosures submitted by directors and discussions with auditors. IAPI assessed that the recording of income originating from Mahata was still too early. "Transactions of US\$239 million are not appropriate if they are recorded as income in 2018. Recording the transaction as revenue should wait for the realization of 
installation of equipment in the framework of services on the aircraft and amortized during the contract period," said Tarko.

\section{Garuda Indonesia restatement on the annual financial report 2018}

PT Garuda Indonesia (Persero) Tbk released its 2018 financial report, which recorded a net loss of

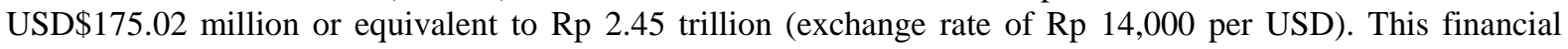
report was revised by Garuda after the decision of the Ministry of Finance, the Financial Services Authority, and the Supreme Audit Agency (BPK) that the Garuda Indonesia financial statements 2018 needed to be restated. They should also follow-up on the decision of the Indonesia Stock Exchange (BEI), instructing that the Q1 financial statements 2019 Garuda Indonesia also be restated. In fact, in a previous report, Garuda recorded a net profit of USD\$5.01 million which later became additionally problematic (Akhir, 2019).

At the restatement of the 2018 Financial Report, Garuda Indonesia recorded an operating income statement of US\$4.37 billion, unchanged from the previous income report. Meanwhile, other operating income was corrected to USD\$38.8 Million from the previous USD\$278.8 million. In the meantime, the Garuda Indonesia restatement report in Q1-2019 (Quarter 1-2019) recorded several adjustments to the asset indicator, including a downward revision to USD\$4.328 Million from the previous USD\$4.532 million. The change in the total asset indicator was due to an adjustment in the recording of Other Receivables to USD\$19.7 million from the previous USD283.8 million. The deferred tax assets were also adjusted to USD \$105.5 million from USD \$45.3 million.

The company's liability in the presentation of the return on the first quarter of 2019 financial statements was also adjusted to USD\$3.537 million from the previous USD\$3.561 million. The restatement of income for the 2018 book period and the first quarter of 2019 is a form of the company's follow-up on the results of the regulator's decision related to the financial performance report.

Besides, referring to the records on the revised Garuda financial statement, Garuda Indonesia has changed and restated the consolidated financial report for the year ending December 31, 2018, and dated March 28, 2019, which has been approved at the General Meeting of Shareholders on April 24, 2019, for the Company's Annual Shares. Garuda Indonesia has amended and restated the consolidated financial statements for the year ending December 31, 2018, dated March 28, 2019, which have been approved by the Company's AGMS on April 24, 2019. Restatement of the consolidated financial statements was primarily related to the transaction cooperation agreement for the provision of connectivity services of in-flight entertainment content management with PT Mahata Aero Teknologi.

The company receives written orders from the Financial Services Authority to make repairs and restatement of the consolidated financial statements for the year ending December 31, 2018. Accordingly, Letter No. S21/PM.1/2019, dated June 28, 2019, is related to the inaccurate application accounting standard PSAK 30 paragraphs 50, and interpretation of Financial Accounting Standards, ISAK 8 paragraph 6. Garuda Indonesia has reviewed the Mahata transaction and decided that confession income from all rights, to compensation costs and installation of connectivity service equipment inside flights should not be recognized at the same time as other income based on PSAK 23 "Revenue". Paragraph 14 in consolidated financial statements before being amended and restated for the year ended December 31, 2018.

Finally, as Laucereno (2019, 28 June) explained, the Republic of Indonesia Financial Services Authority imposed sanctions on Garuda as a publicly listed company, board of directors, and commissioner. Where first for Garuda as an issuer subject to a fine of Rp 100 million. Second, Directors who sign financial statements are subject to Rp 100 million each. Third, collectively directors and Commissioners (except those without signatures) are also fined $\mathrm{Rp} 100$ million.

\section{What are the basic principles of Accounting based on Accrual or Cash?}

According to Utami (2018), it is a common business practice to start with cash-based accounting methods because of their simplicity and then switches to accrual methods as they grow because they allow a more indepth analysis of business finance. In many cases, companies are forced to switch from cash-based methods to accruals because they change from single traders to limited companies, or because of increasing annual turnover. 
But if you read the explanation written by Aldin (2019), Garuda Indonesia admitted that it had not received payment from the collaboration with Mahata Aero Teknologi. In fact, in the Garuda 2018 financial report, the company entered this cooperation into the income post, so the GIAA-coded company was able to record a net profit of US\$5.02 million. This was also supported by Jannah (2019), who wrote that the Director of Finance and Management of PT Garuda Indonesia, Fuad Rizal, admitted that he had not received payment from Mahata Aero Teknologi, the company holding the exclusive rights of the WiFi network operator on the Garuda Group aircraft. Fuad said that he had issued an invoice related to Mahata compensation worth US\$239.9 million so that it was listed as a receivable and included other income components. The same explanation was also written by Ningsih (2019). The Indonesian state-owned airline PT Garuda Indonesia Tbk (GIAA) finally admitted that it had not received payments from a cooperation agreement with Mahata Aero Teknologi. The recognition was a clarification of the irregularities in Garuda's financial statements to date, where previously Garuda had included payments worth US\$241.94 million into the revenue post, even though the status was still receivable.

To reiterate, the author will again quote the definition of accrual-based accounting methods, as written by Kabanga (2018). Accrual Basis is a method of recording transactions with a recording feature, whereby transactions can be recorded because the transaction has money coming in or going out in the future. Transactions are recorded when they occur even if the money has not been issued or received. In other words, the accrual basis is used to measure assets, liabilities, and net assets. Accrual basis recognizes the effect of transactions and other events when they occur, regardless of when cash or cash equivalents are paid or received. The Cash Basis Accounting method is one of the most important concepts in accounting, where the recording of cash bases is a recording technique when transactions occur and the money is received or issued.

Therefore, it can be seen that the method of accounting records conducted by Accrual-based Garuda auditors was not cash-based. Its records in the form of the Mahata payment commitment to Garuda were carried out without regard to the cash flow received. According to articles written by Sugiyanto, Rasyid et al. (2014), the International Federation of Accountants (IFAC), as the compilation body of international accounting standards, suggests the implementation of an accrual basis for the public sector. In more depth, Study\#14, IFAC Public Sector Committee (2002), states that accrual-based reporting is useful in evaluating government performance related to service costs, efficiency, and achievement of goals. This is also in line with articles written by Ferryono and Sutaryo (2017) of the European Commission on Modernizing the EU. Accounts quoted by the Ministry of Finance of the Republic of Indonesia (2014) explain that the benefits of accrual-based accounting make for effective decision-making because it has more comprehensive information and more effective audits. After all, accrual accounting provides clear and coherent records, increases political control through a better understanding of the impact of financial information on policies, and minimizes the risk of errors in payments. So, the selection of accrual-based accounting methods by Garuda Indonesia was more precise and efficient for corporate financial management. This is in line with research conducted by Kwon (1989) which states that accrual-based accounting information is more efficient than cash-based.

\section{The following are the opinions and arguments of the author}

The impetus for the transaction between Garuda and Mahata was the former's initiative to provide free internet access to its customers. In this case, the startup company, Mahata, dared to provide unpaid internet technology, with the concept of providing exclusive rights to install connectivity services in each Garuda Indonesia Group flight. To obtain this right, Mahata was obliged to pay US\$239.94 million to Garuda in the form of accounts receivable. The advantage gained by Mahata is from advertisers who appear on the internet service, where the average number of Garuda Group passengers counts 45 to 55 million passengers per year. And this collaboration has a duration of 15 years.

Meanwhile, Mahata has forged cooperation contracts with numerous well-known companies, such as Lufthansa Technik, Lufthansa Systems, and Inmarsat. In April 2019, Mahata received a sum of US\$21 million from Well Vintage Enterprise FZE Dubai, a financial management consulting company established in 2007 and headquartered in Singapore. Besides that, Mahata is also part of the Mahata Group with a business value of US\$640.5 million. So within 15 years, Mahata will benefit from every advertiser who enters with an average of around 137 thousand passengers every day who will have the potential to see the ad, where the author reckons Mahata will benefit around one dollar for everyone who sees the ad.

So, simply, on the one hand, Garuda will have free internet access facilities for all its customers and on the other hand, Mahata will get exclusive service rights to advertise on every plane that is part of the Garuda Indonesia Group, with the potential for a large number of passengers every day. This shows a beneficial 
symbiosis of mutualism between the two parties. However, the recording of this transaction has pros and cons. At the General Meeting of Shareholders to ratify the annual financial report that had been audited by a trusted public accounting firm, getting a rejection from two of its commissioners who express their disapproval of the Mahata transaction placement in other profit section, with the argument that no money has been entered into the treasury of Garuda, and should the transaction be recorded as accounts receivable. When this is done it will have a very big impact on Garuda's financial statements, which changed the company's net profit position from the previous 2017 deficit of US\$213.39 million to a surplus of US\$5.02, this accounting method caused Garuda's directors to be called by various parties such as Indonesian People's Representative Council, Financial Services Authority and financial audit agency. What, the parties will ask, was the main reason for Garuda to place the transaction in the other profit section. Where this raises the suspicion of various parties who suspect this report was engineered or beautified so that it looked good.

Despite the various things that the author has tried to review, then, the full explanation is as follows. Recognition of income from compensation costs for rights as explained in the restatement of 2018 financial statements should have been recognized based on PSAK 30 "Rent." Garuda Indonesia recognizes revenue for each aircraft which has installed connectivity service equipment and has provided in-flight connectivity services (aircraft connected) during the period cooperation. As of December 31, 2018, Mahata had completed the installation and activation of just one connected aircraft, but the Group did not recognize rental income for one connected aircraft in its financial statements. The amended and restated consolidation taking into account the amount is immaterial. The company had received the Report of Results Management Compliance Checks, the contents of which, among others, recommended that the company revisit the consolidation of its financial statements of 2018 due to an error in the presentation of other income accounts and other receivables. Referring to the Audit Board of the Republic of Indonesia on financial statement (BPK LHP), the Company also conducted a study returning to the cooperation agreement with Mahata related to the indication of Mahata's inability to carry out part of its large scope of work or to pay the fees for compensation rights according to the invoice deadline. The status of the cooperation agreement is unclear and potentially has no legal force, or risk operational to be faced in the implementation cooperation agreement. This can result in possible misinterpretation of facts and has implications for errors in the application of accounting policies and recognition of income above cooperation agreement.

In the end, the author argues that the process of understanding accrual-based accounting transactions is indeed not easy, given the many interpretations that emphasize how financial records must always be based on the money that enters and exits the company's cash flow. A comprehensive explanatory process is needed so that the transition of recording cash-based financial statements into accruals runs smoothly and can be understood by all financial report users in Indonesia.

\section{CONCLUSION}

Recognition of transaction revenues made by Garuda against Mahata is following the Statement of Financial Accounting Standards-PSAK 23 paragraph 29-which states that income arising from the use of entity assets by other parties, and that generate interest, royalties, and dividends, is recognized if the economic benefits of the assets flow to the entity and the amount of revenue can be measured reliably. As stated in the Cooperation Agreement for providing in-flight connectivity services, PT Citilink Indonesia is to receive economic benefits in the form of improving service quality and revenue potential. The Cooperation Agreement also states the number of compensation costs and the allocation of slots from connected planes. So that income from PT Mahata Aero Teknologi can be measured reliably.

Until finally, misinterpretation of facts and misapplication of accounting policies for revenue recognition have impacted the recording and disclosure of the report on consolidated finances for the year ending 31 December 2018. Garuda Indonesia is required to apply PSAK 25 "Accounting Policies, Changes in Estimates Accounting, and Mistakes," and hence Garuda Indonesia must change and restate (based on PSAK 30 "Lease") financial statements for the year ended December 31, 2018. Besides that, this was related to indications of Mahata's inability to carry out part of its large scope of work, or to pay fees and compensation rights according to the invoice deadline. The status of the cooperation agreement is unclear and potentially has no legal force. It risks rendering the cooperation agreement inoperational. 


\section{REFERENCES}

Afandi, J. (2018, 31 October). "Pengakuan Pendapatan menurut SAK dan Pengakuan Pendapatan menurut SAP." Retrieved 28 May, 2019, from https://www.ksap.org/sap/pengakuan-pendapatan-menurut-sakdan-pengakuan-pendapatan-menurut-sap/.

Akhir, D. J. (2019, July 26). "Revisi Laporan Keuangan 2018, Garuda Indonesia Rugi Rp2,4 Triliun." Retrieved February 11, 2020, from https://economy.okezone.com/read/2019/07/26/278/2083785/revisilaporan-keuangan-2018-garuda-indonesia-rugi-rp2-4-triliun.

AkuntansiPedia. (2017, 3 March). "Pengakuan Pendapatan Berdasarkan PSAK 23." Retrieved 1 June, 2019, from http://akuntansipedia.com/pengakuan-pendapatan-psak23/\#.

Aldin, I. U. (2019, 7 May). "Kisruh Laporan Keuangan, Garuda Akui Belum Terima Bayaran dari Mahata." Retrieved 17 June, 2019, from https://katadata.co.id/berita/2019/05/07/kisruh-laporan-keuangan-garudaakui-belum-terima-bayaran-dari-mahata.

Ayu. (2018, 12 October). "Perbedaan dari Akuntansi Basis Akrual (Accrual Basis) dengan Akuntansi Basis Kas (Cash Basis)." Retrieved 16 June, 2019, from https://ukirama.com/blogs/perbedaan-dari-akuntansibasis-akrual-accrual-basis-dengan-akuntansi-basis-kas-cash-basis.

CNN-Indonesia. (2019, 24 April). "Membedah Keanehan Laporan Keuangan Garuda Indonesia 2018." Retrieved 21 May, 2019, from https:/www.cnnindonesia.com/ekonomi/20190424204726-92389396/membedah-keanehan-laporan-keuangan-garuda-indonesia-2018.

DosenAkuntansi. (2018, 17 April). "Contoh Piutang Pendapatan Terlengkap Beserta Penjelasannya." Retrieved 1 June, 2019, from https://dosenakuntansi.com/contoh-piutang-pendapatan.

Ferryono, B. and Sutaryo (2017). "Manfaat Akuntansi Basis Akrual dan Akuntansi Basis Kas Menuju Akrual dalam Pengambilan Keputusan Internal Pemerintah Daerah." Jurnal Dinamika Akuntansi dan Bisnis4(1): 143-160.

Finansialku. (2017, 17 August). "Definisi Akrual Adalah." $\quad$ Retrieved 16 June, 2019, from https://www.finansialku.com/definisi-akrual/.

Ibrahim, I. and R. Binekasri. (2019, 30 April). "Garuda Indonesia Bersikukuh Laporan Keuangan 2018 Tak Langgar PSAK 23." $\quad$ Retrieved $21 \quad$ May, 2019, from https://www.jawapos.com/ekonomi/bisnis/30/04/2019/garuda-indonesia-bersikukuh-laporan-keuangan2018-tak-langgar-psak-23/.

Jannah, S. M. (2019, 6 May). "Garuda Indonesia Belum Terima Pembayaran dari Mahata." Retrieved 16 June, 2019, from https://tirto.id/garuda-indonesia-belum-terima-pembayaran-dari-mahata-driL.

Kabanga, D. (2018, 14 August). "Sistem informasi akuntansi berbasis Kas Vs Basis akrual." Retrieved 16 June, 2019, from http://www.integrasi-edukasi.org/sistem-informasi-akuntansi-berbasis-kas-vs-basis-akrual/.

Kwon, Y. K. (1989). "Accrual Versus Cash-Basis Accounting Methods: An Agency-Theoretic Comparison." Journal of Accounting and Public Policy8(x): 267-281.

Lauceren, S. F. (2019, 28 June). "Laporan Keuangan Cacat, Direksi Garuda Didenda Rp 100 Juta." Retrieved 2 May, 2020, from https://finance.detik.com/bursa-dan-valas/d-4603624/laporan-keuangan-cacat-direksigaruda-didenda-rp-100-juta.

Melani, A. (2019, 17 June). "Kemenkeu Duga Laporan Keuangan Garuda Belum Sesuai Standar Akuntansi, Ini Usul IAPI." Retrieved 18 June, 2019, from https://www.liputan6.com/bisnis/read/3991128/kemenkeuduga-laporan-keuangan-garuda-belum-sesuai-standar-akuntansi-ini-usul-iapi.

Melani, A. (2019, 29 April). "Meneropong Laporan Keuangan Garuda Selama 5 Tahun Terakhir." Retrieved 16 June, 2019, from https://www.liputan6.com/bisnis/read/3952484/meneropong-laporan-keuangangaruda-selama-5-tahun-terakhir.

Ningsih, L. (2019, 7 May). "Ditanya Soal Dana dari Mahata, Garuda: Kami Belum Terima Bayaran." Retrieved 16 June, 2019, from https://www.wartaekonomi.co.id/read226722/ditanya-soal-dana-darimahata-garuda-kami-belum-terima-bayaran.html.

Mufti, R. R. (2019, 2 May). " Garuda argues no flaws in its 2018 financial report" Retrieved 1 May 2020, from https://www.thejakartapost.com/news/2019/05/02/garuda-argues-no-flaws-in-its-2018-financialreport.html

Pradana, R. S. (2019, 29 April). "Ini Penjelasan GIAA Soal Polemik Laporan Keuangan 2018." Retrieved 21 May, 2019, from https://ekonomi.bisnis.com/read/20190429/98/916539/ini-penjelasan-giaa-soalpolemik-laporan-keuangan-2018.

Pratomo, M. N. (2019, 7 May). "Kisruh Lapkeu Garuda Indonesia (GIAA), Begini Penjelasan Auditor Menurut PSAK 23." Retrieved 28 May, 2019, from https://market.bisnis.com/read/20190507/192/919375/kisruhlapkeu-garuda-indonesia-giaa-begini-penjelasan-auditor-menurut-psak-23. 
Rahayu, Y. (2015). "Reformasi Sistem Akuntansi Cash Basis menuju Sistem Akuntansi Accrual Basis." EcodemicaVIII(x): 348-354.

Rosana, F. C. (2019, 15 April). "Laporan Keuangan Garuda Janggal, Ini Keberatan Dua Komisaris." Retrieved 16 June, 2019, from https://bisnis.tempo.co/read/1199049/laporan-keuangan-garuda-janggal-inikeberatan-dua-komisaris/full\&view=ok.

Rustam. (2002). "Pendapatan menurut standar akuntansi keuangan no. 23." Retrieved 1 June, 2019, from http://library.usu.ac.id/download/fe/akuntansi-rustam2.pdf.

Sugianto, D. (2019, 21 May). "Mahata Masih 'Balita', Kok Garuda Bisa Percaya?" Retrieved 28 May, 2019, from https://finance.detik.com/bursa-dan-valas/d-4559144/mahata-masih-balita-kok-garuda-bisa-percaya.

Sugiyanto, H., Y. Y. Rasyid and M. Harjowiryono. (2014). "Gambaran umum akuntansi berbasis akrual." Retrieved 18 June, 2019, from https://muhariefeffendi.files.wordpress.com/2018/08/gambaran-umumakuntansi-berbasis-akrual.pdf.

Sugiyono (2013). Metode Penelitian Manajemen. Bandung, Alfabeta.

Sukmana, Y. (2019, 29 April). "Laporan Keuangannya Tuai Polemik, Ini Penjelasan Garuda Indonesia." Retrieved 16 June, 2019, from https://money.kompas.com/read/2019/04/29/064200526/laporankeuangannya-tuai-polemik-ini-penjelasan-garuda-indonesia-.

Sunyoto, D. (2013). Metode dan Instrumen Penelitian Ekonomi dan Bisnis - Untuk Mahasiswa, Dosen dan Praktisi. Yogyakarta, Center for Academic Publishing Service.

Utami, N. W. (2018, 14 August). "Mengenal Perbedaan Metode Akuntansi Berbasis Kas dan Akrual." Retrieved 16 June, 2019, from https://www.jurnal.id/id/blog/2018-mengenal-perbedaan-metodeakuntansi-berbasis-kas-dan-akrual/. 